\title{
Studies on the Incorporation of $\left[\mathrm{U}-{ }^{14} \mathrm{C}\right] \mathrm{Glucose}$ and $\left[{ }^{35} \mathrm{~S}\right]$ Sulphate into the Acid Glycosaminoglycans of Neonatal Rat Skin
}

\author{
By T. E. HARDINGHAM* AND C. F. PHELPS \\ Department of Biochemistry, University of Bristol, Bristol BS8 1TD, U.K.
}

(Received 24 April 1970)

\begin{abstract}
1. The incorporation of $\left[{ }^{35} \mathrm{~S}\right]$ sulphate in vivo into the acid-soluble intermediates extracted from young rat skin showed three sulphated hexosamine-containing components. 2. The rates of synthesis of these components were determined in vivo by measuring the incorporation of radioactivity from $\left[\mathrm{U}-{ }^{14} \mathrm{C}\right]$ glucose into their isolated hexosamine moieties. 3. The incorporation of radioactivity from $\left[\mathrm{U}-{ }^{14} \mathrm{C}\right] \mathrm{glu}$ cose into the isolated hexosamine and uronic acid moieties of the acid glycosaminoglycans was also measured. These results, combined with those obtained on the intermediary pathways of hexosamine and uronic acid biosynthesis previously determined in this tissue, indicated that the acid-soluble sulphated hexosaminecontaining components were not precursors of the sulphated hexosamine found in the acid glycosaminoglycans. 4. The rates of synthesis of the acid glycosaminoglycan fractions were calculated from the incorporation of radioactivity from $\left[\mathrm{U}-{ }^{14} \mathrm{C}\right]$ glucose into the hexosamine moiety. The sulphated components containing principally dermatan sulphate, chondroitin 6-sulphate and in smaller amounts, chondroitin 4-sulphate, heparan sulphate and heparin appeared to be turning over about twice as rapidly as hyaluronic acid and about four times as rapidly as the small keratan sulphate fraction. The relative rates of synthesis of the sulphated glycosaminoglycans were calculated from the incorporation of $\left.{ }^{35} \mathrm{~S}\right] \mathrm{sulphate}$ and were in agreement with those from ${ }^{14} \mathrm{C}$-labelling studies.
\end{abstract}

A systematic attempt was made in previous papers (Hardingham \& Phelps, 1968, 1970) to document the steady-state contents and turnover times of intermediates in the biosynthesis of acid glycosaminoglycans and to report the type and tissue content of these polymers in neonatal rat skin. It is the object of this paper to report experiments on the incorporation of $\left[\mathrm{U}^{14} \mathrm{C}\right]$ glucose and $\left[{ }^{35} \mathrm{~S}\right]$ sulphate into the acid glycosaminoglycans of this tissue, to describe the sulphated intermediates that occur, to clarify the point at which sulphation occurs during the synthesis of the polymer and to corroborate the rates of polymer production.

\section{MATERIALS AND METHODS}

Materials were as described by Hardingham \& Phelps $(1968,1970)$. Carrier-free $\left[{ }^{35} \mathrm{~S}\right]$ sulphate in aqueous solution was obtained from The Radiochemical Centre, Amersham, Bucks., U.K.

Incorporation of radioactivity into acid glycosaminoglycans in vivo. New born Wistar rats were injected intraperitoneally with either $15 \mu \mathrm{Ci}$ of $\left[{ }^{35} \mathrm{~S}\right]$ sulphate or $5 \mu \mathrm{Ci}$ of $\left[\mathrm{U}-{ }^{14} \mathrm{C}\right]$ glucose $(196 \mathrm{mCi} / \mathrm{mmol})$. After $5 \mathrm{~h}$ at

* Present address: Mathilda and Terence Kennedy Institute of Rheumatology, Hammersmith, London W.6, U.K. $37^{\circ} \mathrm{C}$ in an incubator they were killed and the acid glycosaminoglycans were extracted from the skin and fraction. ated by CPC†-cellulose chromatography as described by Hardingham \& Phelps (1970).

Samples of acid glycosaminoglycans (1-2mg) from individual CPC-cellulose fractions were hydrolysed in $0.05 \mathrm{M}-\mathrm{HCl}$ containing $10-20 \mathrm{mg}$ of Dowex 50 (X 8; $\mathrm{H}^{+}$form; $200-400 \mathrm{mesh}$ ) in a sealed tube at $100^{\circ} \mathrm{C}$ for $24 \mathrm{~h}$ (Anastassiadis \& Common, 1958; Jeffrey \& Reinits, 1966). The hydrolysate and resin were transferred to a column $(3.0 \mathrm{~cm} \times 0.3 \mathrm{~cm})$ of Dowex $50\left(\mathrm{X} \mathrm{8} ; \mathrm{H}^{+}\right.$form; $200-400$ mesh) which was washed through with $5 \mathrm{ml}$ of water, and the hexosamine-containing fractions were eluted with $5 \mathrm{ml}$ of $0.5 \mathrm{M}-\mathrm{HCl}$. The combined water eluate and washings were adjusted to $\mathrm{pH} 9.0$ with $\mathrm{M}-\mathrm{NaOH}$ to convert the hexuronolactone into the free-acid form. It was then applied to a column $(3.0 \mathrm{~cm} \times 0.3 \mathrm{~cm})$ of Dowex 1 (X 8; $\mathrm{Cl}^{-}$form; $200-400 \mathrm{mesh}$ ) and washed with $5 \mathrm{ml}$ of water. The water eluate contained any neutral sugars present. The fraction containing the uronic acid was eluted with $5 \mathrm{ml}$ of $0.2 \mathrm{M}$ HCl. The three fractions thus isolated (hexosamine, uronic acid and 'neutral') were freeze-dried and assayed for hexosamine and uronic acid. No cross-contamination was found between the hexosamine and uronic acid fractions, but the 'neutral' fraction occasionally contained a small amount of uronic acid, presumably derived from unconverted lactone; when present it accounted for less than $10 \%$ of the total isolated uronic acid.

† Abbreviation: CPC, cetylpyridinium chloride. 
Incorporation of radioactivity from $\left[{ }^{35} \mathrm{~S}\right]$ sulphate into acid-soluble intermediates. Newborn rats were each injected as above with $15 \mu \mathrm{Ci}$ of $\left[{ }^{35} \mathrm{~S}\right]$ sulphate. The acidsoluble extract was prepared and chromatographed on a column $(20 \mathrm{~cm} \times 1 \mathrm{~cm})$ of Dowex 1 (X8; formate form; 200-400 mesh) as described by Hardingham \& Phelps (1968); sodium formate was used instead of ammonium formate in the eluant. This substitution had no significant effect on the elution sequence of known compounds. The extended gradient elution of the column was continued further by an additional eluant in the reservoir containing 1.5 $\mathrm{m}$-sodium formate in $4 \mathrm{M}$-formic acid (Fig. 1). Fractions were pooled, passed through Dowex 50 ( $\mathrm{H}^{+}$form) and freeze-dried as described by Hardingham \& Phelps (1968).

Incorporation of radioactivity from $\left[\mathrm{U}-{ }^{14} \mathrm{C}\right]$ glucose into acid-soluble components containing sulphate and hexosamine. Newborn rats were each injected as above with $5 \mu \mathrm{Ci}$ of [U- ${ }^{14} \mathrm{C}$ ]glucose and $10 \mu \mathrm{Ci}$ of $\left[{ }^{35} \mathrm{~S}\right]$ sulphate. The $\left[{ }^{35} \mathrm{~S}\right]-$ sulphate was included to make the peaks more easily recognizable when the extract was ohromatographed on the Dowex 1 (formate) system as described above. The specific radioactivity of the isolated hexosamine of peaks 2,4 and 6 (Fig. 1) were determined in the extract 90 and

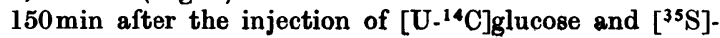
sulphate. The specific radioactivity of glucose was also determined in both extracts and the specific radioactivities of hexose monophosphate, UDP-N-acetylhexosamine, $N$ acetylglucosamine 6 -phosphate and UDP-hexose were determined in the extract $150 \mathrm{~min}$ after injection. Intermediates were isolated and assayed as described by Hardingham \& Phelps (1968).

Electrophoresis. Aoid glycosaminoglycans were submitted to electrophoresis on cellulose acetate strips in $0.2 \mathrm{M}^{-\mathrm{ZnSO}_{4}}$ as described by Hardingham \& Phelps (1970). After staining with Alcian Blue and scanning, $0.4 \mathrm{~cm}$ sections from the origin to beyond the component of highest mobility were cut out and counted for radioactivity in a liquid-scintillation spectrometer. The counting rate was not corrected for the presence of Alcian Blue. When amounts of Alcian Blue similar to that present in the sections were added to acid glycosaminoglycans of known specific radioactivity, there was no significant change in the counting rate.

Radioactivity counting. Water-based samples of up to $0.3 \mathrm{ml}$ in volume were counted for radioactivity in lowbackground glass vials containing $8 \mathrm{ml}$ of scintillation fluid [toluene-2-methoxyethanol $(3: 2, \mathrm{v} / \mathrm{v})$ containing $80 \mathrm{~g}$ of naphthalene and $4 \mathrm{~g}$ of 2,5-bis-(5-tert.-butylbenzoxazol-2-yl)thiophen/1] in a Nuclear-Chicago Mk. 1 liquidscintillation system. An external standard was used to correct for quenching in the samples. Sections from electrophoresis strips were counted for radioactivity in vials with $10 \mathrm{ml}$ of the above scintillation liquid.

Assays. Hexosamine was assayed by the methods of Blix (1948) or Good \& Bessman (1964). Sulphate was assayed after hydrolysis in $3 \mathrm{M}-\mathrm{HCl}$ at $100^{\circ} \mathrm{C}$ for $4 \mathrm{~h}$ by the method of Dodgson (1961). Uronic acid was assayed by the method of Bitter \& Muir (1962) and hexose by the anthrone method of Yemm \& Willis (1954).

\section{RESULTS AND DISCUSSION}

The experiments reported below fall into three schemes. In the first, the acid-soluble extract of young rat skin was examined for possible sulphated intermediates of acid glycosaminoglycan biosynthesis. In the second part, the incorporation of radioactivity from [U- $\left.{ }^{14} \mathrm{C}\right]$ glucose and $\left[{ }^{35} \mathrm{~S}\right]$ sulphate into isolated acid glycosaminoglycan fractions was measured. In the third part, the flow of radioactivity from $\left[\mathrm{U}-{ }^{14} \mathrm{C}\right]$ glucose into the hexosamine moiety of the sulphated intermediates was measured, and in conjunction with the results of Hardingham \& Phelps (1968), the fluxes through these components were calculated by assuming certain product-precursor relationships. The compatibility of these results with the appearance of radioactivity in the polymers was used to discriminate between spurious and real intermediates of glycosaminoglycan biosynthesis.

Sulphated intermediary metabolites. The skins of rats that had been injected with $\left[{ }^{35} \mathrm{~S}\right]$ sulphate were extracted and the acid-soluble intermediates were subjected to chromatography in a Dowex-1 (formate) system as described above. The six ${ }^{35}$ S-labelled fractions (Fig. 1) were assayed for their total bound hexosamine contents (Good \& Bessman, 1964) after hydrolysis with acid. Three conditions of hydrolysis were used: $(a)$ 0.05M-hydrochloric acid at $100^{\circ} \mathrm{C}$ for $30 \mathrm{~min}$, sufficient to hydrolyse nucleotide sugars, (b) $\mathrm{M}$-hydrochloric acid at $100^{\circ} \mathrm{C}$ for $1 \mathrm{~h}$, sufficient to hydrolyse ester sulphate substituents on hexosamine and (c) $3.8 \mathrm{M}$-hydrochloric acid at $100^{\circ} \mathrm{C}$ for $6 \mathrm{~h}$, which is probably adequate to split all the glycosidic linkages involving hexosamine. Only peaks 2,4 and 6 contained hexosamine (Table 1).

The hexosamine in the 3.8 $\mathrm{M}$-hydrochloric acid hydrolysate of peak 2 was identified as galactos. amine by t.l.c. on silica gel (Hardingham \& Phelps, 1968). The original substance gave only a weak Morgan-Elson reaction after hydrolysis in $0.05 \mathrm{M}$ hydrochloric acid followed by acetylation (Good \& Bessman, 1964) but complete reaction if hydrolysis was effected in M-hydrochloric acid (Table 1). One might deduce from these findings that the galactosamine is substituted at its 4-position. The substance may be UDP- $N$-acetylgalactosamine 4sulphate, which occurs in extracts of the isthmus of hen oviduct (Strominger, 1955) and of epiphyseal cartilage and aorta of the young rat (Picard \& Gardais, 1967). We have not shown this conclusively, partly because the amount present in the extract $(12 \pm 4 \mathrm{nmol} / \mathrm{g}$ wet wt. of tissue) was small. The presence of a small and variable amount of uronic acid in the fraction (Table 1) was not unexpected as its position of elution from the Dowex 1 column overlapped slightly with that of UDP-glucuronic acid (Hardingham \& Phelps, 1968).

The materials of both peaks 4 and 6 showed only galactosamine on t.l.c. of their amino sugars 


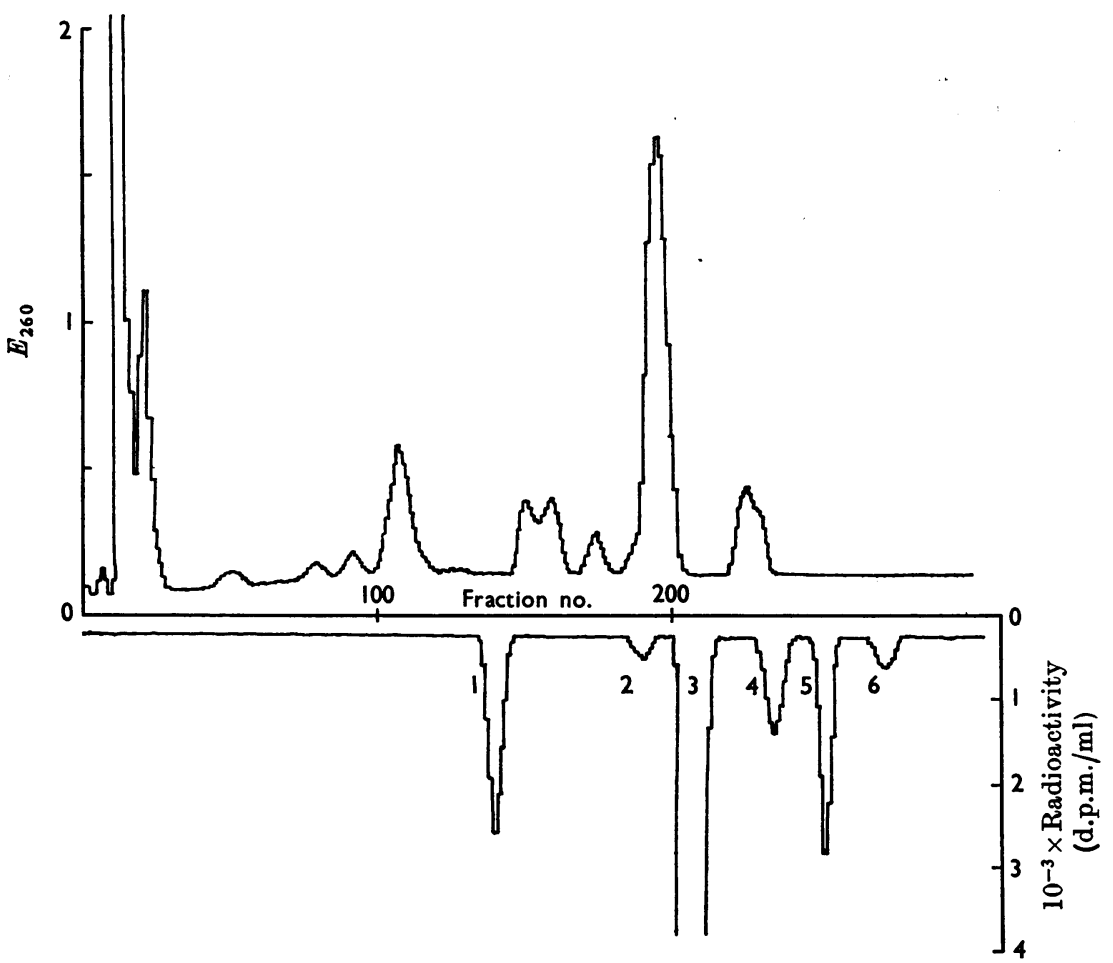

Fig. 1. Nucleotide and radioactivity profiles of the acid-soluble extract of $6 \mathrm{~g}$ (wet wt.) of neonatal rat skin $1 \mathrm{~h}$ after injection of $\left.{ }^{35} \mathrm{~S}\right]$ sulphate. A column $(20 \mathrm{~cm} \times 1 \mathrm{~cm})$ of Dowex 1 (X 8; formate form; $200-400$ mesh) was eluted with an extended gradient formed with a $220 \mathrm{ml}$ sealed mixing vessel and reservoir containing various concentrations of formic acid and sodium formate as follows: fraction nos. 0-100, $4 \mathrm{M}$-formic acid; fraction nos. 100-150, $4 \mathrm{M}$-formic acid + 0.25 M-sodium formate; fraction nos. 150-195, $4 \mathrm{M}$-formic acid+ $0.40 \mathrm{M}$-sodium formate; fraction nos. 195-230, $4 \mathrm{M}$-formic acid $+0.80 \mathrm{M}$-sodium formate; fraction nos. 230$280,4 \mathrm{M}$-formic acid $+1.50 \mathrm{M}$-sodium formate.

Table 1. Uronic acid and hexosamine assays of ${ }^{35} \mathrm{~S}$-labelled peaks separated by Dowex 1 (formate form) chromatography of the acid-soluble extract

The peaks refer to those of Fig. 1.

Hexosamine (nmol)

$\begin{array}{ccccc} & \begin{array}{c}\text { Hydrolysed by } \\ \text { Peak }\end{array} & \begin{array}{c}\text { Hydrolysed by } \\ 1.0 \mathrm{M}-\mathrm{HCl}\end{array} & \begin{array}{c}\text { Hydrolysed by } \\ 3.8 \mathrm{M}-\mathrm{HCl}\end{array} & \begin{array}{c}\text { Uronic acid } \\ \text { (nmol) }\end{array} \\ 1 & 0 & 0 & 4 & 4 \\ 2 & 12 & 120 & 110 & 16 \\ 3 & 0 & 0 & 0 & 0 \\ 4 & 0 & 8 & 352 & 386 \\ 5 & 0 & 0 & 2 & 1 \\ 6 & 0 & 2 & 206 & 244\end{array}$

(Hardingham \& Phelps, 1968), and they reacted to the Morgan-Elson test only after complete hydrolysis in 3.8M-hydrochloric acid followed by $N$ acetylation. As they also contained equimolar amounts of hexosamine and uronic acid (Table 1), they appeared to be sulphated glucosaminoglycans.
Further experiments showed peak 4 material to be excluded from Sephadex G-25, but it was lost on dialysis overnight from Visking $8 / 32$ tubing which had been heated at $100^{\circ} \mathrm{C}$ for $6 \mathrm{~h}$ in several changes of water to decrease its permeability (M. Luscombe, personal communication). This suggested that the 
molecular weight of the material in peak 4 was not greatly in excess of 5000, the upper limit of resolution of polysaccharide on Sephadex G-25. Not enough of peak 6 material was obtained for gel chromatography.

The materials in peaks 1,3 and 5 contained no hexosamine or uronic acid. Peak 3 was in the same position as inorganic sulphate, and the substance contained most of the radioactivity present in the extract. The compounds in peaks 3 and 5 were completely destroyed by heating at $37^{\circ} \mathrm{C}$ and $\mathrm{pH} 1.0$ for $1 \mathrm{~h}$. These are conditions under which adenosine $5^{\prime}$-phosphosulphate and $3^{\prime}$-phosphoadenosine $5^{\prime}$ phosphosulphate are degraded (Robbins, 1963). We have not further characterized the substances in these peaks.

The acid-soluble extract thus revealed three ${ }^{35} \mathrm{~S}$-labelled components containing hexosamine. Peaks 4 and 6 showed the characteristics of glycosaminoglycan chains. Peak 2 appeared to be the only potential sulphated intermediate of hexosamine metabolism.

Radioactive labelling of glycosaminoglycans. The specific radioactivities of the glycosaminoglycan

Table 2. Specific radioactivity of monosaccharides isolated from neonatal rat skin 5 h after injection of [U. $\left.{ }^{14} \mathrm{C}\right]-$ glucose

Fractions were eluted from CPC-cellulose columns and identified as described by Hardingham \& Phelps (1970).

\begin{tabular}{|c|c|c|c|c|c|}
\hline \multirow[b]{2}{*}{ Fraction } & \multirow[b]{2}{*}{ Identification } & \multicolumn{2}{|c|}{$\begin{array}{l}\text { Specific radioactivity } \\
\text { (d.p.m./ } \mu \mathrm{mol} \text { ) }\end{array}$} & \multirow{2}{*}{$\begin{array}{c}\text { Sp.-radioactivity } \\
\text { ratio } \\
\left(\frac{\text { hexosamine }}{\text { uronic acid }}\right)\end{array}$} & \multirow{2}{*}{$\begin{array}{c}\text { Radioactivity ratio of } \\
\text { disaccharide unit } \\
\left(\frac{\text { after hydrolysis* }}{\text { before hydrolysis }}\right) \\
(\%)\end{array}$} \\
\hline & & Hexosamine & $\begin{array}{l}\text { Uronic } \\
\text { acid }\end{array}$ & & \\
\hline $1 \% \operatorname{CPC}(a)$ & $\begin{array}{l}\text { Keratan } \\
\text { sulphate }\end{array}$ & 2450 & 一 & 一 & - \\
\hline $1 \% \mathrm{CPC}(b)$ & $\begin{array}{l}\text { Heparan } \\
\text { sulphate? }\end{array}$ & 8100 & 5030 & 1.61 & 92 \\
\hline $0.3 \mathrm{~m}-\mathrm{NaCl}$ & $\begin{array}{l}\text { Hyaluronic } \\
\text { acid } \\
\text { Heparan }\end{array}$ & 3630 & 1950 & 1.86 & 101 \\
\hline $0.3 \mathrm{M}-\mathrm{MgCl}_{2}$ & $\left\{\begin{array}{l}\text { sulphate, } \\
\text { dermatan } \\
\text { sulphate? } \\
\text { Dermatan } \\
\text { sulphate, }\end{array}\right.$ & 9400 & 5200 & 1.81 & 98 \\
\hline $0.7 \mathrm{M}-\mathrm{MgCl}_{2}$ & $\begin{array}{l}\text { chondroitin } \\
6 \text {-sulphate, } \\
\text { chondroitin } \\
\text { 4-sulphate }\end{array}$ & 10000 & 4360 & 2.30 & 91 \\
\hline $1.25 \mathrm{M}-\mathrm{MgCl}_{2}$ & Heparin & 8700 & 4400 & 1.97 & 86 \\
\hline \multicolumn{6}{|c|}{ * For explanation see the text. } \\
\hline
\end{tabular}

Table 3. Incorporation of $\left[{ }^{35} \mathrm{~S}\right]$ sulphate into acid glycosaminoglycans of neonatal rat skin 5 h after injection Fractions were eluted from CPC-cellulose columns as described by Hardingham \& Phelps (1970).

\begin{tabular}{|c|c|c|c|c|c|}
\hline \multirow[b]{2}{*}{ Fraction } & \multirow{2}{*}{$\begin{array}{c}10^{-5} \times\left[{ }^{35} \mathrm{~S}\right] \text { sulphate } \\
\text { radioactivity } \\
\text { (d.p.m. } / \mu \mathrm{mol})\end{array}$} & \multirow{2}{*}{$\begin{array}{l}\frac{\text { Sulphate }}{\text { hexosamine }} \\
\text { molar ratio* }\end{array}$} & \multirow{2}{*}{$\begin{array}{l}\% \text { of total } \\
{\left[{ }^{35} \text { S]sulphate }\right.} \\
\text { incorporated }\end{array}$} & \multicolumn{2}{|c|}{$\begin{array}{l}\text { Relative rate of } \\
\text { synthesis from }\end{array}$} \\
\hline & & & & ${ }^{35} \mathrm{~S}$ labelling & ${ }^{14} \mathrm{C}$ labelling \\
\hline $1 \% \operatorname{CPC}(a)$ & 1.66 & $1.00 \dagger$ & 2.46 & 0.32 & 0.29 \\
\hline $1 \% \operatorname{CPC}(b)$ & 3.07 & 0.80 & 4.59 & 0.77 & 1.19 \\
\hline $0.3 \mathrm{~m}-\mathrm{NaCl}$ & 2.87 & 0.02 & 1.24 & - & 6.72 \\
\hline $0.3 \mathrm{M}-\mathrm{MgCl}_{2}$ & 5.00 & 0.90 & 8.80 & 1.25 & 1.48 \\
\hline $0.7 \mathrm{M}-\mathrm{MgCl}_{2}$ & 6.34 & 1.03 & 71.4 & 8.86 & 8.11 \\
\hline $1.25 \mathrm{M}-\mathrm{MgCl}_{2}$ & 5.27 & 1.45 & 11.47 & 1.00 & 1.00 \\
\hline & $\begin{array}{l}* \text { Taken fr } \\
\dagger \text { Assumed }\end{array}$ & $\begin{array}{l}\text { rdingham } \\
\text { for compar }\end{array}$ & $(1970)$ & & \\
\hline
\end{tabular}


fractions of young rat skin were measured $5 \mathrm{~h}$ after the injection of [U- $\left.{ }^{14} \mathrm{C}\right]$ glucose (Table 2). There was good agreement between the combined specific radioactivities of the isolated hexosamine and uronic acid components and the specific radioactivities of the glycosaminoglycans from which they were derived (Table 2, column 5). This suggested that the isolated sugars were representative of the glycosaminoglycan fractions in spite of incomplete recoveries, which ranged from 60-90\% for hexosamine and $40-80 \%$ for uronic acid.

The specific radioactivity of the fractionated acid glycosaminoglycans $5 \mathrm{~h}$ after injection of [ $\left.{ }^{35} \mathrm{~S}\right]$ sulphate is shown in Table 3 . The variation in specific radioactivity of these fractions was similar to that found from ${ }^{14} \mathrm{C}$-incorporation studies. Hyaluronic acid, the major component of the 0.3 M-sodium chloride fraction, is a non-sulphated glycosaminoglycan but the presence of a small amount of radioactivity suggested a minor sulphated component to be present; its specific radioactivity was similar to that found in the $1 \%$ CPCcellulose (b) fraction.

In the ${ }^{14} \mathrm{C}$-labelling experiments the radioactivity was distributed in both the uronic acid and hexosamine components of the glycosaminoglycans (Table 2). These are incorporated in equimolar amounts from their nucleotide sugar derivatives. Thus for hyaluronic acid radioactivity is incorporated from UDP-glucuronic acid and UDP- $N$ acetylglucosamine, as shown by Glaser \& Brown (1955) and Markowitz, Cifonelli \& Dorfman (1959). Similarly, for sulphated glycosaminoglycans the radioactivity is derived from UDP-glucuronic acid and UDP- $N$-acetylglucosamine or UDP- $N$-acetylgalactosamine. Dermatan sulphate differs from the other sulphated glycosaminoglycans in that it contains iduronic acid instead of glucuronic acid. UDP-iduronic acid has been shown to be derived from UDP-glucuronic acid in rabbit skin (Jacobson \& Davidson, 1962) and presumably this is the route by which the iduronic acid which forms part of dermatan sulphate is produced. Thus if the specific radioactivity of UDP-iduronic acid differed greatly from that of UDP-glucuronic acid it would alter the radioactivity incorporated into the uronic acid of the dermatan sulphate. UDP-iduronic acid was tested for but not identified in the acid-soluble extract of young rat skin (Hardingham \& Phelps, 1968). It possibly occurred at a very low concentration ( $<5 \mathrm{nmol} / \mathrm{g}$ wet wt. of tissue) in which case the effect on the radioactivity incorporated into the iduronic acid of dermatan sulphate would be minimal. The general similarity of labelling in chondroitin sulphate and dermatan sulphate in the 0.7 M-magnesium chloride CPC-cellulose fraction from the $\left[\mathrm{U}-{ }^{14} \mathrm{C}\right]$ glucose experiments (Table 4) suggested that the labelling of iduronic acid was not greatly different from the labelling of the glucuronic acid of the other acid glycosaminoglycans.

Both UDP- $N$-acetylglucosamine and UDP- $N$ acetylgalactosamine were shown to be of equal specific radioactivity, and thus in equilibrium with each other at all times tested, in skin derived from young rats that had been injected with [U- ${ }^{14} \mathrm{C}$ ]glucose (Hardingham \& Phelps, 1968). The radioactivity incorporated into sulphated glycosaminoglycans would thus be independent of which hexosamine was present, but there are two possible routes for the incorporation of sulphate, involving sulphation either before or after polymerization.

Sulphation after polymerization would have no effect on the radioactivity incorporated into a sulphated as opposed to a non-sulphated glycosaminoglycan, but sulphation before polymerization implies the presence of a sulphated hexosamine intermediate. Passage of radioactivity through an extra intermediate after UDP- $N$-acetylhexosamine would undoubtedly decrease the amount of label appearing in the sulphated hexosamine of the product, and thus also alter the ratio of radioactivity in uronic acid to that in hexosamine. However, the ratios of specific radioactivities in hexosamine to that in uronic acid of the sulphated fractions (Table 2) were similar to the analagous ratio in the fraction that was unsulphated and largely consisted of hyaluronic acid, and where mixed fractions were examined by electrophoresis (Table 4) there was

Table 4. Electrophoresis of ${ }^{14} \mathrm{C}$-labelled $0.3 \mathrm{M}$-magnesium chloride and $0.7 \mathrm{M}$-magnesium chloride fractions in 0.2M-zinc sulphate $\mathrm{pH} 4.8$

Two components were separated in each electrophoresis experiment as shown by Hardingham \& Phelps (1970).

'Slow/fast' ratio from

\section{Fraction \\ $0.3 \mathrm{M}-\mathrm{MgCl}_{2}\left\{\begin{array}{l}\text { slow } \\ \text { fast } \\ 0.7 \mathrm{M}-\mathrm{MgCl}_{2}\end{array}\left\{\begin{array}{l}\text { slow } \\ \text { fast }\end{array}\right.\right.$}

Component

Heparan sulphate

Possibly dermatan sulphate

Dermatan sulphate

Chondroitin 6- and 4-sulphate

$\begin{array}{ccc}\text { Staining } & \text { Radioactivity } & \begin{array}{c}\text { Sp. radioactivity } \\ (a)\end{array} \\ (b) & (b / a) \\ 1.20 & 1.10 & 0.92 \\ 1.0 & 1.0 & 1.0 \\ 1.68 & 2.00 & 1.19 \\ 1.0 & 1.0 & 1.0\end{array}$


Table 5. Specific radioactivity of the hexosamine isolated from peaks 2,4 and 6 and of other intermediates 90 min and 150 min after injection of $\left[\mathrm{U}-{ }^{14} \mathrm{C}\right]$ glucose

Peaks are as defined in the legend to Fig. 1.

\begin{tabular}{lcc} 
& $10^{-3} \times$ Sp. radioactivity (d.p.m./ $\mu \mathrm{mol}$ ) \\
\cline { 2 - 3 } Peak 2 & $150 \mathrm{~min}$. & $90 \mathrm{~min}$. \\
Peak 4 & 28.8 & 8.35 \\
Peak 6 & 20.4 & 5.88 \\
Glucose & 3.4 & $0.78^{*}$ \\
Hexose monophosphate & 57.6 & 78.0 \\
$N$-Acetylglucosamine 6-phosphate & 64.0 & \\
UDP- $N$-acetylhexosamine & 74.0 & \\
UDP-hexose & 87.0 & \\
\multicolumn{2}{c}{ * Counted at only $50 \%$ above background. }
\end{tabular}

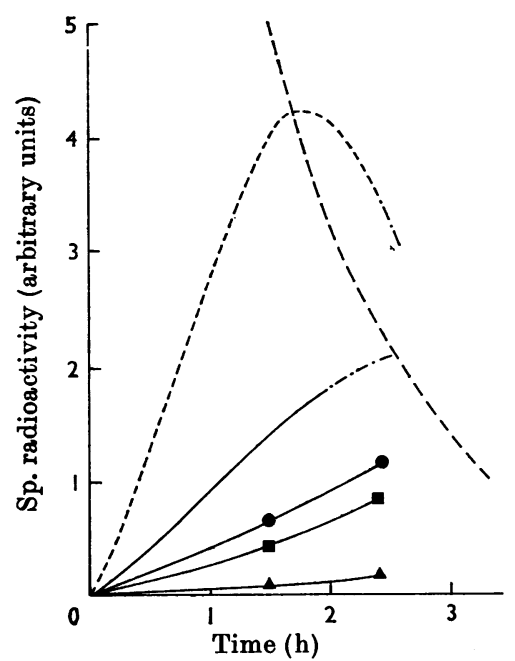

Fig. 2. Time-course of variation of specific radioactivity of the hexosamine of peaks $2(\bullet), 4(\square)$ and $6(\Delta)$ isolated from neonatal rat skin after the injection of $\left[\mathrm{U}-{ }^{14} \mathrm{C}\right]$ glucose. The results for UDP- $N$-acetylhexosamine (-...), UDP-glucuronic acid (-) and glucose (-- ) (Hardingham \& Phelps, 1968) are also shown.

no indication of large differences in specific radioactivity, which might reflect different ratios not revealed in the whole fractions.

These results are thus consistent with sulphation occurring largely after the polymerization reaction. It does not, however, exclude the remote possibility that hyaluronic acid is produced as a sulphated polymer, which undergoes desulphation before extrusion from the cell, and it does not rule out the presence of a small pool of sulphated intermediate turning over rapidly. As a possible intermediate of sulphated hexosamine metabolism was identified in the acid-soluble extract of the tissue, the latter possibility was further investigated.

${ }^{14} \mathrm{C}$ labelling of the acid-soluble sulphated intermediates. The specific radioactivities of the isolated hexosamine fractions of peaks 2, 4 and 6 (Fig. 1) were determined 90 and $150 \mathrm{~min}$ after the injection of $\left[\mathrm{U} \cdot{ }^{14} \mathrm{C}\right]$ glucose (Table 5). The specific radioactivities of glucose and the other intermediates (Table 5) allowed these results to be correlated with previous results on the flux through the hexosamine pathway (Hardingham \& Phelps, 1968) to produce Fig. 2. (It is to be noted that, in error, in Fig. 3 of this previous publication the labels of UDP. $N$ acetylhexosamine and $N$-acetylglucosamine 6 phosphate were transposed. The curve for UDP- $N$ acetylhexosamine now appears correctly in Fig. 2 of the present paper.) Although no productprecursor relationships were demonstrated, the initial part of the time-course of variation of specific radioactivity of the hexosamine of peaks 2,4 and 6 was sufficient for possible rates of turnover to be calculated by assuming various product-precursor relationships (Table 6).

When calculated as a product of UDP- $N$ acetylhexosamine, peak 2 showed the fastest turnover of the three sulphated hexosamine components. However, this rate of turnover would account for less than $1 \%$ of the flux through UDP- $N$-acetylhexosamine. Thus if peak 2 , and not UDP- $N$-acetylhexosamine, were incorporated into a sulphated glycosaminoglycan, the radioactivity in the hexosamine of the polymer would be very much decreased. In view of the similarity of the ratios of incorporation into hexosamine and uronic acid of the glycosaminoglycan fractions, and the low flux through the peak 2 hexosamine moiety, it can be clearly concluded that peak 2 was not on the main pathway of hexosamine biosynthesis of any major sulphated glycosaminoglycan present in this 


\section{Table 6. Possible product-precursor relationships of peaks 2,4 and 6 and $U D P-\mathrm{N}$-acetylhexosamine}

The results were calculated as described by Hardingham \& Phelps (1968). Abbreviation: UDPHexNAc, UDP- $N$-acetylhexosamine.

Peak 2 as a product of UDPHexNAc Peak 4 as a product of UDPHexNAc Peak 6 as a product of UDPHexNAc Peak 4 as a product of peak 2

Peak 6 as a product of peak 2

Peak 6 as a product of peak 4

$\begin{gathered}\text { Tissue content } \\ \text { of product } \\ \text { (nmol/g wet wt.) } \\ 12 \pm 4 \\ 41 \pm 10 \\ 28 \pm 5 \\ 41 \pm 10 \\ 28 \pm 5 \\ 28 \pm 5\end{gathered}$

Rate of synthesis of product (pmol/min per $\mathrm{g}$ wet wt. of tissue) 18 34 0.38 87 33 46 tissue. The labelling of peaks 4 and 6, together with their tissue contents, imply that they have an even lower turnover, (Table 6). Their origin and significance remain for the present unknown.

Calculation of the turnover rates of the acid glycosaminoglycans from ${ }^{14} \mathrm{C}$ labelling. In estimating the rates of biosynthesis in vivo of a mixed glycosaminoglycan population it is not sufficient to assume that the incorporation of radioactivity into the fractions from a common precursor such as glucose is proportional to their rates of synthesis. The glycosaminoglycans identified in this tissue (Hardingham \& Phelps, 1970) contain variously glucosamine, galactosamine, galactose, glucuronic acid and iduronic acid as major components, and the marked differences in radioactive labelling of these components in their intermediary pathways of metabolism is evident from previous work (Hardingham \& Phelps, 1968). A notable exception was $N$-acetylglucosamine and $N$-acetylgalactosamine which, as their UDP derivatives, appeared to form a common pool of very similar specific radioactivity. In the present study an examination of the acid-soluble extract of the tissue and the incorporation of radioactivity into the acid glycosaminoglycans showed no evidence for the participation of sulphated hexosamine intermediates, on an extensive scale, in the biosynthesis of acid glycosaminoglycans. The functioning of a common UDP- $N$ acetylhexosamine pool and the absence of further intermediates appeared to be a reasonable basis for the assumption that in this tissue the incorporation of radioactivity from $\left[\mathrm{U} \cdot{ }^{14} \mathrm{C}\right]$ glucose into the hexosamine of each glycosaminoglycan was proportional to their rates of synthesis. The relative rates of synthesis of all the fractions were thus calculated on this basis (Table 3).

The rates of flux through UDP- $N$-acetylhexosamine and UDP-glucuronic acid were determined in this tissue by Hardingham \& Phelps (1968). Hexosamine and uronic acid are incorporated in equimolar amounts into uronic acid-containing glycosaminoglycans. The flux through the hexosamine pathway was considerably higher than that through the uronic acid pathway; the latter thus presents a limiting value for the rate of biosynthesis of uronic acid-containing glycosaminoglycans, assuming it all to be used in this way. The flux through UDP-glucuronic acid was thus divided among the uronic acid-containing glycosaminoglycan fractions according to their relative rates of synthesis (from Table 3), to give an estimate of their absolute rates of synthesis, and, together with their tissue contents, their turnover times (Table 7). The rate of synthesis of the keratan sulphate fraction that contains no uronic acid was calculated in proportion to the other fractions from its relative rate of synthesis (Table 7). Except for keratan sulphate, the sulphated acid glycosaminoglycans appeared to be turning over far more rapidly than hyaluronic acid. The most rapid turnover time was $3.00 \pm 0.56$ days for the 0.7 M-magnesium chloride fraction. The separation of dermatan sulphate from the chondroitin sulphates in this fraction showed it to have an even faster turnover time (Table 4). The other sulphated fractions had turnover times of 3.7-4.2 days, but that of keratan sulphate was more than three times as long, $12.6 \pm 2.8$ days.

Calculation of rates of synthesis of sulphated glycosaminoglycans from ${ }^{35} \mathrm{~S}$ labelling. It was assumed that the incorporation of $\left[{ }^{35} \mathrm{~S}\right]$ sulphate was proportional to the rate of synthesis of polymer sulphate groups, and that the radioactive polymers synthesized had the same degree of sulphation as the fraction in which they were isolated. The degree of sulphation was then allowed for in using these results to compare the rates of synthesis of the different fractions. Thus for each fraction:

$$
\begin{aligned}
& \frac{\mathrm{d}}{\mathrm{d} t}\left({ }^{35} \mathrm{~S} \text { incorporated }\right) \times \\
& \frac{\text { hexosamine }(\mathrm{mol})}{\text { sulphate }(\mathrm{mol})} \propto \text { rate of polymer synthesis }
\end{aligned}
$$


Table 7. Rates of synthesis of acid glycosaminoglycans in vivo calculated from the radioactive incorporation from glucose and the precursor flux through UDP-glucuronic acid

The fractions are the same as those in Table 2. The results were calculated as described by Hardingham \& Phelps (1968).

\begin{tabular}{|c|c|c|c|}
\hline Fraction & $\begin{array}{c}\text { Rate of } \\
\text { synthesis } \\
\text { (nmol/h per g wet } \\
\text { wt. of skin) }\end{array}$ & $\begin{array}{l}\text { Tissue content* } \\
\text { of hexosamine } \\
\text { (nmol/g wet } \\
\text { wt. of skin) }\end{array}$ & $\begin{array}{c}\text { Turnover time } \\
\text { (days) }\end{array}$ \\
\hline $1 \% \operatorname{CPC}(a)$ & 0.225 & $68 \pm 7$ & $12.6 \pm 2.8$ \\
\hline $1 \%$ CPC (b) & 0.925 & $92 \pm 9$ & $4.14 \pm 0.90$ \\
\hline $0.3 \mathrm{M}-\mathrm{NaCl}$ & 5.227 & $950 \pm 40$ & $7.57 \pm 0.26$ \\
\hline $0.3 \mathrm{M}-\mathrm{MgCl}_{2}$ & 1.156 & $110 \pm 9$ & $3.96 \pm 0.82$ \\
\hline $0.7 \mathrm{M}-\mathrm{MgCl}_{2}$ & 6.305 & $452 \pm 28$ & $3.00 \pm 0.56$ \\
\hline $1.25 \mathrm{M}-\mathrm{MgCl}_{2}$ & 0.778 & $70 \pm 6$ & $3.75 \pm 0.79$ \\
\hline
\end{tabular}

* Taken from Hardingham \& Phelps (1970).

By using this relationship the proportional rates of synthesis were calculated (Table 3). The degree of sulphation of the $1 \%$ CPC-cellulose $(a)$ fraction was not known because of other substances interfering with the assay, but for comparison with other fractions a value of 1.0 was assumed.

\section{DISCUSSION}

Considerable evidence has been presented to demonstrate the ability of preparations from various tissues to transfer sulphate in vitro on to intact polysaccharide chains (e.g. D'Abramo \& Lipmann, 1957; Suzuki, Threnn \& Strominger, 1961 ; Meezan \& Davidson, 1967; Silbert \& De Luca, 1969). The present results imply that sulphation of the glycosaminoglycans of young rat skin in vivo also largely occurs after polymerization of the polysaccharide chains.

These findings, together with previous work, which showed UDP- $N$-acetylglucosamine and UDP$N$-acetylgalactosamine to be labelled in a similar way, suggested the use of the incorporation of radioactivity from $\left[\mathrm{U}_{-}{ }^{14} \mathrm{C}\right]$ glucose into the hexosamine as a measure of the rate of synthesis of the acid glycosaminoglycan fractions. Calculated on this basis, the dermatan sulphate and chondroitin sulphate fractions showed the fastest turnover of all the fractions, and all the sulphated glycosaminoglycan fractions, except keratan sulphate, had a much faster turnover rate than hyaluronic acid. The results from $\left[{ }^{35} \mathrm{~S}\right]$ sulphate incorporation compared well with those from [U- $\left.{ }^{14} \mathrm{C}\right]$ glucose incorporation (Table 3), adding further support to the interpretation of ${ }^{14} \mathrm{C}$ labelling, and again showing the chondroitin sulphate and dermatan sulphate fractions to have the highest rate of synthesis.

In contrast with these results, studies on the skin of mature rats and rabbits (Schiller, Mathews, Cifonelli \& Dorfman, 1956; Davidson, Small,
Perchemlides \& Baxley, 1961) in which the rate of decay of radioactivity was measured in vivo, hyaluronic acid was shown to be more metabolically active than the chondroitin sulphates, but, in view of the close physical relationship that exists between collagen and dermatan sulphate and chondroitin 6-sulphate (see e.g. Mathews, 1965), the enhanced dermatan sulphate and chondroitin sulphate synthesis noted here may occur in parallel with the rapid deposition of collagen that undoubtedly occurs at this early stage of development.

The origin of the two sulphated oligosaccharides revealed by ${ }^{35} \mathrm{~S}$ labelling of the acid-soluble extracts was not clear. Their presence in a fairly constant amount and ratio to each other, and their radioactive labelling, suggested that they were not degradation products. It was not ascertained whether they differed from each other in size or degree of sulphation, although, from the ${ }^{14} \mathrm{C}$ labelling, it was possible that peak 6 material was derived from peak 4 material.

The role of the material of peak 2 also remains obscure. It might function as the sulphated galactosamine donor for a minor glycosaminoglycan constituent of the skin or some, as yet unidentified, sulphated glycoprotein, or it may be spuriously synthesized and reflect nothing more than the lack of specificity of the enzymes responsible for glycosaminoglycan biosynthesis.

We thank the British Insulin Manufacturers Association for a research studentship for T. E. H. and Mrs E. Burd for excellent technical assistance.

\section{REFERENCES}

Anastassiadis, P. A. \& Common, R. H. (1958). Can. J. Biochem. 54, 213.

Bitter, T. \& Muir, H. M. (1962). Analyt. Biochem.4, 330. Blix, G. (1948). Acta chem. scand. 2, 467. 
D'Abramo, F. \& Lipmann, F. (1957). Biochim. biophys. Acta, 25, 211.

Davidson, E. A., Small, W., Perchemlides, P. \& Baxley, W. (1961). Biochim. biophys. Acta, 46, 189.

Dodgson, K. S. (1961). Biochem. J. 78, 312.

Glaser, L. \& Brown, D. H. (1955). Proc. natn. Acad. Sci. U.S.A. 41, 253.

Good, T. A. \& Bessman, S. P. (1964). Analyt. Biochem. 9, 253.

Hardingham, T. E. \& Phelps, C. F. (1968). Biochem. J. 108, 9.

Hardingham, T. E. \& Phelps, C. F. (1970). Biochem. J. 117, 813.

Jacobson, B. \& Davidson, E. A. (1962). J. biol. Chem. 237, 638.

Jeffrey, P. L. \& Reinits, K. G. (1966). Biochim. biophys. Acta, 141, 179.
Markowitz, A., Cifonelli, J. A. \& Dorfman, A. (1959). J. biol. Chem. 234, 2343.

Mathews, M. B. (1965). Biochem.J. 96, 710.

Meezan, E. \& Davidson, E. A. (1967). J. biol. Chem. 242, 1685 .

Picard, J. \& Gardais, A. (1967). Bull. Soc. Chim. biol.49, 1689.

Robbins, P. W. (1963). In Methods of Enzymology, vol. 6, p. 772. Ed. by Colowick, S. P. \& Kaplan, N. O. New York and London: Academic Press.

Schiller, S., Mathews, M. B., Cifonelli, J. A. \& Dorfman, A. (1956). J. biol. Chem. 218, 139.

Silbert, J. E. \& DeLuca, S. (1969). J. biol. Chem. 244, 876.

Strominger, J. L. (1955). Biochim. biophys. Acta, 17, 283.

Suzuki, S., Threnn, R. H. \& Strominger, J. L. (1961). Biochim. biophys. Acta, 50, 169.

Yemm, E. W. \& Willis, A.J. (1954). Biochem.J. 57, 508. 